\title{
Human Capital: Driving Force of Economic Growth in Selected Emergine Economies ${ }^{\oplus}$
}

\author{
Abdul Ghafoor Awan \\ Professor of International Business \& Finance and Dean of Faculties, Institute of Southern Punjab, \\ Multan-Pakistan
}

\begin{abstract}
Human capital is the stock of competencies, knowledge and personality attributes deem vital to produce economic value. It is the attributes gained by a worker through education, training and experience. According to modern growth theory, the accumulation of human capital is an important contributor to economic growth. Numerous cross-country studies extensively explore whether educational attainment can contribute significantly to the production of overall output in an economy. The objective of this paper is to investigate the role of human capital in the fast economic growth of BRIC countries like Brazil, Russia, India and China during 2000-2011 and to assess sustainability of growth in future. The study is descriptive in nature because it mostly involves the description of the situation of human capital in the BRIC countries and measuring change in the selected important variables that is human capital and policy initiative and its effects on the BRIC economies. As the change in the selected variables is clearly visible there is no need to use regression analysis technique. The author has applied statistical techniques such as trend analysis, content analysis and ratio analysis to measure change in the selected variables wherever it is necessary. The findings of the study are interesting and divergent because the human capital development has played a vital role in the fast economic growth of China, India and Brazil while Russia, which was endowed with human capital right from the beginning, could not materialize the potential of human capital during its transition period from planned economy to market economy since 1990s, which is very much surprising. This appears the policy failure to capitalize the valuable human capital to accelerate economic growth. It has resulted in the scaling down of Russia to middle income economy. In contrast, India, China and Brazil have been fully utilizing their human capital potential by following human developing policies and this factor not only has triggered their economic growth but also alleviated poverty in there.
\end{abstract}

Key words: BRIC countries, Economic growth, Human capital, poverty alleviation, educational attainment.

GEL Classification Code: F43; J24

\footnotetext{
${ }^{\oplus}$ This paper was read at It International Conference on Management and Economics held on February 11-12, 2012 in Sahiwal-Pakistan held under the auspices of COMSAT Institute of Information Technology.
}

Copyright (C) 2012, Asian Business Consortium | GDEB 


\section{INTRODUCTION}

China, Russia, India and Brazil are the fast growing economies in the world that are generally named as BRIC countries. These four countries have huge human resources and their total population is about 41 percent of the world, their area is 26 percent of the world and their GDP is 18 percent of world. In size, Russia is the largest country in the world, having $11.5 \%$ of area of the world. China and India are No.1 and No.2 largest populous countries of the world as well as largest countries in Asia and are equal to the United States in terms of size. Brazil is the largest country in Latin America and Southern Hemisphere.

Recently these four countries particularly China and India have attracted the attention of the whole world due to their constant fast economic growth particularly at a time when the advanced economies have been facing economic downturn since 2008. The miraculous growths of BRIC countries have also won the attention of the researchers all over the world. Now the researchers are keenly investigating different aspects of the economic growth of the BRIC countries. As these four countries have abundant human resources and their governments have been following human resources development policies to obtain demographic dividend. The author has intended to analyze the role of human capital in the economic growth of these four countries.

\section{ObJective of Paper}

The objective of this paper is to investigate the role of human capital in the fast economic growth of four "Emerging Economies" during the period of 2000-2010 and to assess sustainability of their growth in future. Another objective of this paper is to analyze the importance of human capital for these countries.

\section{LITERATURE REVIEW}

The concept of human capital was originally formulated by Adam Smith (1776 ed. 1976). In his masterpiece, the author stated that:

"The difference between the most dissimilar characters, between a philosopher and a common street porter, for example, seems to arise not so much from nature, as from habit, custom, and education. When they came into the world, and for the first six or eight years of their existence, they were perhaps, very much alike, and neither their parents nor playfellows could perceive any remarkable difference. About that age, or soon after, they come to be employed in very different occupations. The difference of talents comes then to be taken notice of, and widens by degrees, till at last the vanity of the philosopher is willing to acknowledge scarce any resemblance" "The Wealth of Nations" pag19-20, Book I).

Afterwards, the theory on human capital was formalized by Schultz (1961), Becker (1964) and Mincer $(1974,1988)$. The basic idea of the human capital theory is that the variety of talents is mainly acquired through different activities, such as education or working experience. These activities have a cost, but produce benefits in future. In simple words, human capital acquisition is an asset (Mincer, 1993).

Becker (1964) discusses the formation of human capital through the working experience at specific firms or working places. Workers become more productive and qualified over time thanks to "learning by doing" processes, and as a consequence, their wages will tend to increase. On the supply side, workers are aware that their competences and skills are firmspecific and therefore, the same wage level will be not guaranteed if they move to a different firm. On the demand side, employers tend to hold the most productive workers in their firms by keeping wages and working conditions high. Remuneration and other non-monetary aspects of jobs become, in the author's view, a powerful tool used by firms to reduce turnover 
costs. Both workers and firms have thereby incentives to maintain long run relationships, when investments in education and job formation take place.

Like Becker, Romer (1986) speaks about "learning by doing" processes, but unlike Becker, Romer introduces the term "knowledge" as engine of economic growth. This is a side-product of the production activity, and augments with work. Moreover, knowledge is a public good, non-rival and non-excludable. Therefore once it has been acquired it spills over across the whole economy generating a sustainable economic development.

The most representative model of human capital in the growth literature was elaborated by Lucas (1988). In his two-sector model, the author points out that human capital and knowledge are synonyms and are a voluntary outcome of the learning process. Based on his theoretical setting, some authors of the new growth literature (Mankiw et al. 1992; Barro and Sala-i-Martin 1997; Acemoglu and Angris 1999; Krueger and Lindhal 2001) have empirically proved that the stock of human capital plays an extremely important role in promoting economic growth and prosperity (Mankiw et al., 1992).

On the basis of a review of the relevant literature, we reach the following broad conclusions. First, investment in human capital contributes significantly to productivity growth.

Second, there is clear evidence that human capital plays a key role in fostering technological change and diffusion.

Third, human capital investment appears attractive relative to alternative assets, both from the individual and from the aggregate perspectives.

Fourth, policies that raise the quantity and quality of the stock of human capital are compatible with increasing social cohesion.

\section{MetHodology}

This study is descriptive in nature because it mostly involves the description of the four economies and important selected variables. As the change in the selected variables is clearly visible there is no need to use regression analysis. The author have applied trend analysis, contend analysis and ratio analysis techniques wherever they are necessary.

\section{SAMPLE}

Out of a dozen Emerging economies the author has selected four fast emerging economies such as China, India, Russia and Brazil because these four economies are representatives of all emerging economies. Most of social and economic indicators of these countries have improved substantially since 2000 due to their growth-oriented policies, opening of world markets, high commodity prices and transformation of human resources to human capital.

\section{Selected Variables}

- $\quad$ Literacy Rate.

- School enrolment rates.

- Average years of schooling.

- Employment rates.

- Foreign Direct Investment

\section{Study Period}

The period of study is spread over ten years (2000-2010). During this period the BRIC economies recorded tremendous economic growth, breaking all previous record. 


\section{DATA AND SOURCE}

The author has used secondary data collected from the World Bank, IMF databases, China Bureau of Statistics, US Census Bureau, International statistics, Deutsche Bank Research, US Federal Reserve Bank, International Labour Organization, Barro and Lee data-base (2011) and numerous research papers.

\section{What is Human Capital?}

The founder of Economics, Adam Smith defined human capital as follows:

"The acquisition of such talents and useful abilities of all inhabitants or members of the society during their education, study, or apprenticeship, always costs a real expense, which is a capital fixed and realized, as it were, in their person. These talented persons as they make a part of their fortune as well as benefit the society to which they belong. The improved dexterity of a workman may be considered in the same way as a machine or instrument of trade which facilitates and abridges labor, and which, though it costs a certain expense, repays that expense with a profit. The productive power of labor depends on the division of labor based on skill." In this definition, Adam Smith draws a line of demarcation between raw labor and human capital, saying that talent persons not only make their fortune but also benefit to the society. He emphasized that the labor must be divided into two groups, one which has no education and experience should be assigned the task of physical work and one who are educated and skilled should be assigned the tasks according to its education and skill. He also emphasized that skilled and unskilled workers should not be treated equally and their work should be divided accordingly. This is the only way one can exploit the productive power of labour, he suggested.

\section{Origin of the term "Human CAPITAL"}

The use of the term "Human Capital" in the modern neoclassical economic literature dates back to Jacob Mincer's article "Investment in Human Capital and Personal Income distribution" in The Journal of Political Economy in 1958, Then T.W. Schultz (1961) also contributed to the development of the subject matter. The best-known application of the idea of "human capital" in economics is that of Gray Becker's book entitled "Human Capital", published in 1964 that became a standard reference for many years. According to these authors, human capital can be developed by investing in education, training and health care. Human capital is a mean of production, into which additional investment yields additional output. Human capital is substitutable, but not transferable like land, labor, or fixed capital. Modern growth theory sees human capital as an important determinant of economic growth.

\section{Human Capital Contribution to Economic Growth}

According to the theory of endogenous growth, human capital contributes to economic growth at least in three ways.

1. It raises productivity of workers due to upgraded skills and better education.

2. It is a source of new ideas and innovations.

3. It facilitates dissemination and embeddedness of new ideas and practices leading to more effective economic performance (Romer, 1989, 1990; Lucas, 1988; Aghion and Howitt, 1992).

\section{Competency and Human Capital}

Competency is the knowledge that is achieved through continuous learning and experience. Unlike other factors of production like labour and physical capital the competency has following characteristics: 
1. Expandable and self generating as it is used. For example, as doctors work more they get more experience, their competency increased. In this way the economics of scarcity is replaced by the economics of self-generation.

2. Transportable and shareable: competence, especially knowledge, can be moved and shared. This transfer does not prevent its use by the original holder. However, the transfer of knowledge may reduce its scarcity-value to its original possessor. This is assumed to be externality effect.

\section{Human Capital Formation in BRIC Countries}

The concept of Human capital is more important in labor-surplus countries. These countries are naturally endowed with more of labor due to high birth rate. The surplus labor in China, India, Brazil and Russia is the human resource available in more abundance than the tangible capital resources. This human resource can be transformed into Human capital with effective inputs of education, training, health and moral values. The transformation of raw human resource into highly productive human resource with these inputs is the process of human capital formation. The problem of scarcity of tangible capital in these countries can be resolved by accelerating the rate of human capital formation with both private and public investment in education and health sectors. The tangible financial capital is an effective instrument of promoting economic growth. The intangible human capital, on the other hand, is an instrument of promoting economic development because human capital is directly related to human development, and when there is human development, the qualitative and quantitative progress is inevitable.

The BRIC economies are rapidly moving towards innovation due to increase in research activities there. According to UNESCO Institute of Statistics, the number of researchers, on the rise world-wide, jumped by 56\% in developing countries between 2002 and 2007, In comparison, their number increased by only $8.6 \%$ in developed countries during the same period. In five years, the number of researchers in the world rose significantly, from 5.8 to 7.1 million. The greatest gain was made in developing countries: 2.7 million researchers were counted in 2007, versus 1.8 million five years earlier. These countries increased their global share of researchers from $30.3 \%$ in 2002 to $38.4 \%$.

The biggest increase was seen in Asia, whose share went up from 35.7\% in 2002 to $41.4 \%$. China is mainly responsible for the gain, having gone from 14 to $20 \%$ in five years. The increase in Asia occurred at the expense of Europe and the Americas, whose shares went down respectively from 31.9 to $28.4 \%$ and from 28.1 to $25.8 \%$.

\section{HOW HUMAN CAPITAL CREATES COMPETITIVE ADVANTAGE?}

Human capital includes knowledge, wisdom, expertise, intuition and ability of individuals to realize national tasks and goals. Human capital constitutes populations' total capabilities as reflected in education, knowledge, health, experience, motivation, intuition, entrepreneurship and expertise; in addition a highly skilled labour force, the availability of scientists and engineers, a female labor force and health (life expectancy, physicians) are good indicators. These elements represent the key success factors in creating a competitive advantage for a nation in the present and future. Human capital provides the resources for the development and cultivation of other areas of intellectual assets such as R\& D and training, as the human factors is so important link in the process of value creation. Human capital represents the necessary lever that enables value creation from all other components that have turned out to be key source of wealth at national level (Malhotra 2000).

Human Capital can create competitive advantage if is sufficiently different from competitors 
(Alvarez and Barney, 2011). Taken to extreme- if all countries possess the same human capital, there would be no competitive advantage. In the BRIC countries human capital is more heterogeneous and rather scarce than in highly developed countries. An example is literacy rate which is considerably higher in advanced countries than in developing countries (see UNDP, 1998).Therefore; human capital is more likely to create competitive advantage in the BRIC countries.

The entrepreneurship literature provides a number of arguments on how human capital should increase entrepreneurial success. First, human capital increases the capability of owners to perform the generic entrepreneurial tasks of discovering and exploiting business opportunities (Shane and Venkatraman, 2000). For example, prior knowledge increase owners' entrepreneurial alertness (cf.Westhead et al., 2005) preparing them to discover specific opportunities that are not visible to other people (Shane, 2000; Venkatraman, 1997). Additionally, human capital affects owners' approaches to the exploitation of opportunities (Chandler and Hanks, 1994; Shane, 2000). Second, human capital is positively related to planning and venture strategy, which in turn, positively impacts success (Baum et a., 2001; Frese et al.,2007). Third, knowledge is helpful for acquiring other utilitarian resources such as financial and physical capital (Brush et al,2001) and can partially compensate a lack of financial capital which is a constraint for many entrepreneurial firms (Chandler and Hanks,1998). Finally, human capital is a prerequisite for further learning and assists in the accumulation of new knowledge and skills (e.g. Ackerman and Humphreys,1990; Hunter,1986). Taken together, owners with higher human capital should be more effective and efficient in running their business than owners with lower human capital. The same theory is applied on countries having high and lower lever of human capital. The countries having high level of human capital will be successful in exploitation of opportunities, technology and markets.

Now we turn to assess the situation of human capital in BRIC countries.

\section{Human Capital in China}

China has a population of about 1.35 billion in 2010 and its annual population growth rate was 0.48.China has undertaken "one child policy" since 1979 with specific objective of curtailing population. According to Greenhalgh (2003) estimate this policy has prevented around 300 to 400 million extra births during 1980-2005, which brought a dramatic impact on China's economic and societal development. Weil (2009) estimates that, there were only 70 million children in China by 2000 as a result of one-child policy. Li and Zhang (2007) show that a decline of the birth rate by $1 / 1000$ increases the economic growth rate by an estimated 0.9 percent per year. They also argue that the steady-state GDP capita would be raised by 14.3 percent.

$\mathrm{Yu}$ (2011) sketch a very interesting picture of Chinese economic growth. He says that by averting average 13 million births per year accelerated economic growth. He calculated that without one-child policy the real GDP per capital would have lower by 13.2 percent. He concluded that high ratio of working to non-working (1.81) led to higher savings, higher savings led to a higher level of investment and the large capital stock led to high output. This altogether ended in an economic take-off effect. Cehn and Hao (2010) argue that due to the one-child policy more women were released to the labor market which added to the working age population and explosion of economic growth rate due to rising participation of women at labor market. Cal and Wang (2006), Yu (2011), Wang Mason (2008) have concluded that the demographic transition during last few decades is responsible for one-six to two-fifth of China's GDP per capita growth since 1978.

Chen and Liu (2009) argue that together with economic reforms undertaken since 1978, China 
has been able to profit a lot from demographic dividend. They predict that China will continue to reap benefit from demographic dividend till 2033.

It is interesting to note how China transformed its raw labour into human capital. The population, which was a burden and major cause of China's underdevelopment in the early few decades, became a valuable asset since 1980. The reason is that in 1950 around 69.8 percent of China's population was illiterate and had no schooling. This kept China poor and a backward country. While in 2010 it was only 6.5 percent illiterate population. The average years of schooling in 1950 was only 1.5 percent in China while in 2010 it was 8.16 years. The average number of years of schooling in the world was 8.12 years in 2010. (Barro and Lee's (2010) data set). It shows that China is ahead of world average years of schooling. So the growth of human capital is fast in China vis-a-vis other emerging economies.

With foreign reserves approached \$3.27 trillion in the mid of 2012, the country is well positioned to fund all of its educational and health projects, basis business capital costs for years to come. For the better part of the 21st Century, China has also been the destination of choice for western multinationals keen to build or partner with that government in developing an Asian manufacturing base. In 1980, China accounted for 1 percent of global GDP.As of 2012, its share had increased to 9 percent of world GDP. The entry of US, Europe and Japan's multinational companies into China added many benefits to the Chinese economy in the form of FDI, transfer of technology and improvement of technical skill of Chinese labour.

\section{Policies AND their positive impact on Chinese Economy}

In 1978 more than $82 \%$ Chinese population was lived in the rural areas while only 18 percent population was lived in urban areas but now situation is quite different because around 50 percent population lived in the urban areas. The poverty ratio in the rural areas in 1978 was 32 percent which has reduced to around 5 percent in 2010. This was happened due to economic reforms introduced during 1979-1984 when rural communes were dismantled and reorganized and the peasants were given control over the use of land without having the right to sell. The farmers were encouraged to diversify production to more high-value cash produces. Crops prices were increased to 30 percent, besides supplying inputs at subsidized rates. All this led to increase in agriculture income and reduced poverty because more cultivators were net sellers of both cash crops and food grains. Periodically, the policy initiatives taken by Chinese Government have been divided into three phases:-

1. 1979-84: Pro-farmers policies brought agricultural transformation, massive increase in rural income and saving and release surplus of labor to industry.

2. 1984-92: Policies accelerated growth of Township-Village Enterprises (TVEs) through exploration of rural savings and demand and simultaneous explosion of FDI from overseas Chinese, in Special Economic Zones and related coastal areas, primarily for export of labor-intensive light manufacturing.

3. 1992-2000: Proliferation of Multinational Investment in heavier, more capital and technology intensive industries and infrastructures, mainly for domestic market and nontradable sector. According to World Bank 2002 estimates, the magnitude of poverty has reduced to 6 percent in China from 22 percent in 1990.

4. 1980-2005: Education promotion policies have brought significant effect on the development of human resources and it can be visualized from the following table:- 
Table 1: Human capital in China: Rates of Educated workforce-2007

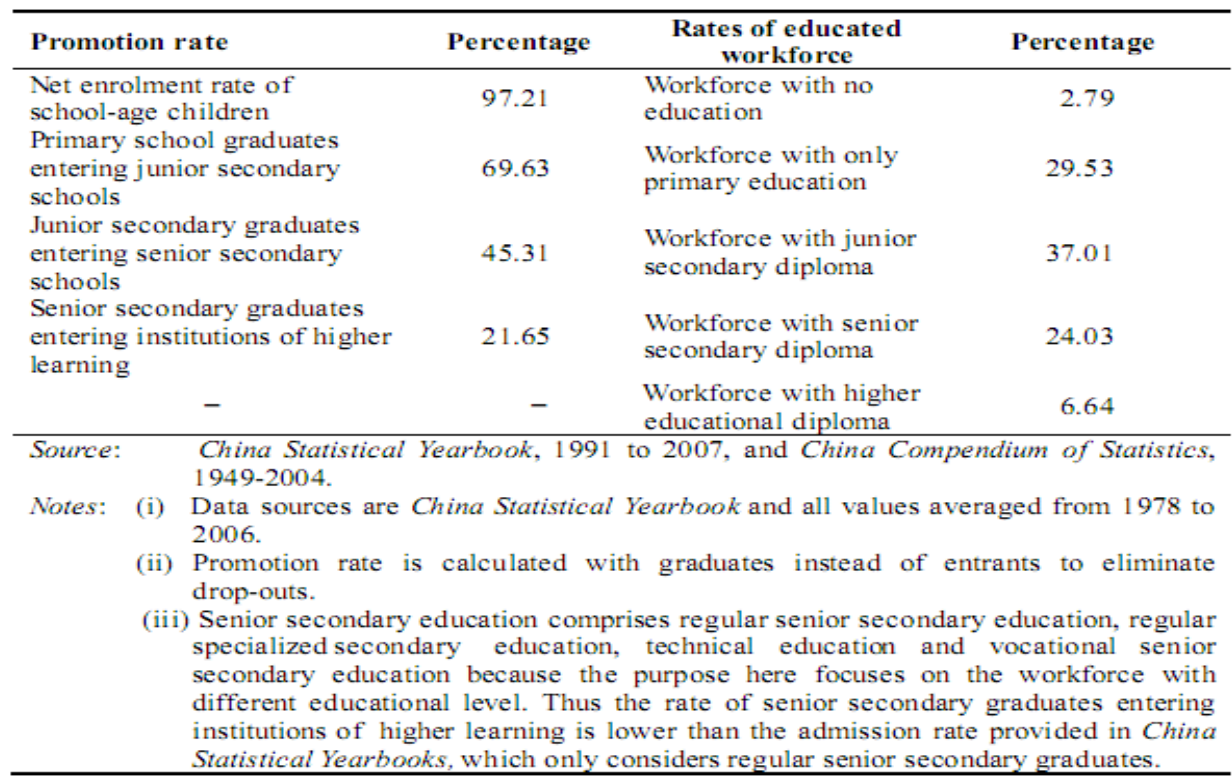

As Schultz (1961) wrote, investment in human capital and economic growth are directly linked. The transition from large families to smaller families' brings one significant change: the enhancement of investment in human capital. Becker et al (1990) describe two steady-states: one with large families and small investment in human capital and one with small families and rising investment in human capital. They state that the idea that a country can switch its steady-state given certain policies and adequate living standard. The one child policy artificially accelerated the speed of this transition through exogenously influencing the family size. This forced China to switch from one steady-state to the other. Subsidizing and supporting public education system can be used to advance higher investment in human capital (Fanti and Gori 2011),Zhang 1997). Since private returns to education at the moment are possibly below its marginal value, as Holz (2008) states, Chine has to invest in the education system to further promote investment in human capital. To give education more weight may help maintain economic growth.

\section{Talents Development in China}

Li and Floridia (2006 say that talent is attracted to the availability of employment opportunities and financial rewards. More recent research identified two additional non-market factors that affect the level and flow of human capital. Operating on the consumption-side, quality of life or urban amenities have been found to matter in the location decisions of human capital households (Glaeser,Kolko, and Saiz,2001; Lloyd,2001; Lloyd and Clark,2001. Florida $(1999,2000,2000 a, 2000 b, 2000 c, 2005 ;$ Florida and Gates,2001) has argued that talent is also attracted to regions that offer low barriers to entry and higher levels of openness and tolerance, measures, for example, by concentration of new immigrants.

Technology and talent have long been seen as driving forces of economic growth. Romer (1986) has established relation between knowledge; human capital and economic growth through his endogenous growth model, arguing that investment in human capital generate spillovers and increasing returns. Florida (2006) pleads that talent is measured as a proxy index 
of the number of universities per capital in each city.

China"s rapidly rising rate of human capital production particularly its huge and growing production of scientists and engineers, alongside rising investments in its universities and academic infrastructure and its growing ability to conduct research and development and attract the R\&D affiliates of foreign multination's. However, Talent, technology and regions output in China are all highly concentrated and uneven. China's top 10 city-regions, which account for 16 percent of its population, account for 43 percent of talent production and 58 percent to technological innovation. Its top 25 regions, which house 30 percent of its people, account for nearly three quarters of talent production and more than 80 percent of technological innovations. And its top 50 regions, which house 52 percent of its population, account for nearly 90 percent of talent and 95 percent of technological innovation. There is extreme concentration of China's economic assets on its eastern coast, providing a map of the major centers of university-based talent production in the coastal cities of Beijing, Nanjing, Wuhan, Guangzhou, Shenshen, and Shanghai.

As China is heading towards innovative economy, it is facing scarcity of talents in different sectors. China had 2.25 million scientists and engineers (S\&Es) in 2004. Its demands for S\&Es were around 2.64 million in 2005 and 3.85 million in 2010. China's future S\&E demand will be 5.9 million in 2015. To meet this shortage China has taken advantage of 2008 financial crisis to lure back talent from overseas. Delegations have been dispatched to the United States and other countries to recruit financial professionals. Most recently, the Department of Organization of the Chinese Communist Party Central Committee launched a Thousands Talent Program, pledging to attract some 2,000 high-end Chinese talents residing overseas in the next 5-10 years. Under the scheme, institutions of learning, enterprises, and other organizations are encouraged to target those leaders who are able to make breakthroughs in key technologies, develop high-tech industries, and pioneer new discipline areas. Domestic companies and MNCs also have put on their agenda to nurture and secure a quality and adaptable workforce find and attract more qualified employees.

Holz (2008) has contended:

"If talent is randomly distributed among the world population and if China's education system is able to identify the brightest students, then China has a larger pool of talent than any other country in the world."

To use human resources more efficiently means more innovations are possible and therefore a higher level of productivity and economic growth occur. In their new five-year plan, China set a target of creating an innovation promoting environment. Ding and Knight (2008) pleads that China is on a better track than other countries in terms of education. He compared China with other developed countries and concludes that the growth rate of human capital is responsible for the growth difference. So the investment in human capital is one major part of growth accounting in China as compared to other countries' growth rate.

\section{Human Capital in Russian Federation}

Russian Federation has a population of 140.87 million with a negative annual population growth rate of -0.51 . It is endowed with human capital right from the beginning. In 1950 the literacy rate in Russia was 85 percent while the percentage of illiterate population was only 15 percent. The literacy rate in 2010 was 91 percent while average years of schooling were 9.69, which was highest among the four selected emerging economies.

Abundance and high quality of national human capital was routinely considered Russia's key competitive advantage. Standard proxies for human capital show high endowments in Russia. According to the data set supplied by Barro and Lee (2001), Russia scored high in education 
attainment rankings during the period 1960-2000, placing it among the top ten of 138 countries. Russia remained almost at par with countries enjoying a very high human development index under the United Nations classification (UNDP, 2010: 143-146). In addition, Russia is ahead of most developed countries on indicators such as enrolment rates, absolute numbers and share of scientists and researchers per million persons, number of graduate and post-graduate students per 10,000 people. The same goes for the formal educational characteristics of the economically active population (see Table 2 )

Table 2: Distribution of Economically Active Population by Education,2001 and 2007

\begin{tabular}{|c|c|c|c|c|c|c|}
\hline \multirow{3}{*}{ Country } & \multicolumn{6}{|c|}{ Share, $\%$} \\
\hline & \multicolumn{2}{|c|}{ Primary or less } & \multicolumn{2}{|c|}{ Secondary } & \multicolumn{2}{|c|}{ Tertiary } \\
\hline & 2001 & 2007 & 2001 & 2007 & 2001 & 2007 \\
\hline USA & 17.1 & 9.5 & 39.5 & 29.4 & 43.3 & 61.1 \\
\hline New Zealand & 20.4 & 17.9 & 49.6 & 41.1 & 27.2 & 37.3 \\
\hline UK & 17.5 & 21.5 & 47.4 & 45.9 & 26.8 & 31.9 \\
\hline Germany & 17.3 & 17.0 & 58.9 & 59.0 & 23.8 & 23.9 \\
\hline France & 26.9 & 26.0 & 46.9 & 44.3 & 26.2 & 29.4 \\
\hline Korea & 14.2 & 23.0 & 43.7 & 42.0 & 24.9 & 35.0 \\
\hline Brazil* & 73.9 & 62.5 & 18.6 & 28.9 & 6.9 & 8.6 \\
\hline Russia & 12.1 & 6.4 & 33.9 & 41.1 & 54.0 & 52.5 \\
\hline
\end{tabular}

Note: * $11+$ years old.

Source: Key Indicators of the Labour Market (KILM). Geneva, ILO. http://www. ilo.org/public/english/employment/strat/kilm/, downloaded on 3 January 2011 .

Sobolevia (2011) argues that during the two post-Soviet decades, this potential competitive advantage was not realized either at the macro or at micro level. Russian industrial sector was unable to produce commodities of good quality and to offer strong incentives for workers and management. Natural resources were misallocated: the significant comparative advantage in the natural sector was fizzled out from resource extraction to refined and processed goods (Russian Academy of Sciences, 2000; Intriligator et al. 2001).

The decline in industrial employment was due to a profound economic crisis and was accompanied by unfavorable changes in the sector as the share of manufacturing value added in GDP declined against a rapid expansion in exports from the extractive sector. The share of mining in overall industrial employment increased from 12.5 per cent in 1990 to 21 per cent in 1998, and 25 per cent at the turn of the millennium, while the corresponding figures for engineering industry were 38, 30 and 27 per cent respectively, for light industry were 11, 6.7 and 6 per cent respectively. Per capita production of basic food products and consumer goods also went down when no signs of basic needs saturation were observed. (See Table 3). 
Table 3 : Employment Distribution by Broad Economic Sectors, Russia, 1992-2004

\begin{tabular}{|c|c|c|c|c|c|c|c|}
\hline \multirow{2}{*}{ Sector of economy } & \multicolumn{7}{|c|}{ Employment (year average) } \\
\hline & 1992 & 1995 & 2000 & 2001 & 2002 & 2003 & 2004 \\
\hline $\begin{array}{l}\text { Agriculture } \\
\text { (thousand persons) }\end{array}$ & 10336 & 10003 & 8609 & 8200 & 7947 & 7480 & 7054 \\
\hline Share $(\%)$ & 14.3 & 15.1 & 13.4 & 12.7 & 12.2 & 11.4 & 10.7 \\
\hline $\begin{array}{l}\text { Manufacturing, mining } \\
\text { \& construction } \\
\text { (thousand persons) }\end{array}$ & 29211 & 23369 & 19545 & 19707 & 19516 & 19425 & 19270 \\
\hline Share $(\%)$ & 40.6 & 35.2 & 30.4 & 30.5 & 29.8 & 29.6 & 29.2 \\
\hline $\begin{array}{l}\text { Services } \\
\quad \text { (thousand persons) }\end{array}$ & 30210 & 31604 & 34135 & 34676 & 35704 & 36440 & 37054 \\
\hline Share $(\%)$ & 41.9 & 46.8 & 53.1 & 53.5 & 54.8 & 55.5 & 56.3 \\
\hline
\end{tabular}

Source: Rosstat, http:/www.gks.ru/wps/wcm/connect/rosstat/rosstatsite/main/, accessed on 3 January 2011.

The former Soviet Union was a leader in different technology fields such as metallurgy, precision instruments, space technologies, computer software, aircraft building and development of new materials. In line with the international standards, the former Soviet Union gained a significant level of development in transport and infrastructure sectors, mass education and in the basic applied research. This progress relied on the valuable science establishment and broad networks between research institutes and experimental laboratories coordinated at national level (Intriligator et al. 2001).

The high quality of human capital was mainly achieved by ensuring that the labour force had a high level of general education. Moreover, the planned system offered a peculiar scheme of non-market incentives (mainly in the form of a high standard of living) to the Russian intellectual elite. Scientists and researchers, therefore, could benefit from a high social status, several fringe benefits and higher wages than those paid to the rest of the economy. In the early 1990's, Russia had 200 university and college students per 10,000 of population, a value which is similar to most developed countries. About $20 \%$ of workers had a university degree, whilst less than 3\% had not graduated from high school. In 1985 Russia alone employed more than 1.2 million research workers and more than 3 million people, if specialists are considered (Romer, 2001, Micklewright 1999).

The new Russia inherited from the former Soviet Union two areas of comparative advantage, one in the resource extraction sector and the other in the human capital sector. While the first area of advantage has already made great strides in the world market, the second one does not keep pace with international standards. Indeed Russia is a net importer in the sectors which make intensive use of human capital. More precisely, the specialization index calculated for 2002 shows that the only human capital intensive products in which Russia is specialized are optical instruments, non-electric engines and steam generating boilers.

The Russian economic transition from a planned to a market economy started with a drastic reform program -a 'Big Bang'- launched by President Boris Yeltsin after October 1991.This reform program envisaged a quick liberalization, a massive privatization and a fast stabilization programmed for the Russian economy. In few months, central controls were outlawed, price and trade barriers were lifted and a colossal privatization agenda started. The immediate effect of this was an increase in the price level and an upsurge in the inflation rate. In the first three years of the radical reforms, real GDP dropped by 33 percent, industrial production by 44 percent and investments by 60 percent (Goskomstat, 2005; Pomer, 2001). 
Over the next four years, albeit at a slower rate, the economic decline continued and the ruble appreciated. Government expenditures, including spending on human capital (science, education, culture, and health care), fell to 37.8 percent of GDP in 1996 and to approximately 35 percent in 1997 (The World Bank, 2001). Relative to 1990, employment in 1998 was off by 11 million workers, poverty became endemic, and social services were halved. The Russian privatization process brought a small group of people to grab a sizeable part of the public wealth, and as a consequence, inequality increased and mafia influence became prominent in several aspects of Russian life (Glinkina et al. 2001).

\section{Negative impact Of Reforms On Human CAPITAL}

The Russian reforms were aimed at a dual goal of facilitating the transition from a centrally planned to a market based economic system and to meet the competitive demands of the global economy, which was both ambitious and associated with grave risks both in the economic and social spheres.

Unfortunately with the lifting of the 'iron curtain' the standard neo-liberal approach to shaping the reforms based on the mainstream economic paradigm institutionalized in the Washington Consensus principles that were adopted, failed to connect effectively with the endowments Russia enjoyed. The selected strategy of minimizing the role of the state in economic and social spheres and rapid privatization consistently implemented in Russia during the first decade of reforms had very controversial results. The spontaneous unleashing of market forces was not accompanied by a coherent state policy aimed at correcting the structural biases in the economy, at the efficient utilization of manpower and accumulation of human capital, and at adequate safety nets for the preservation of the national human resources. Social policy of the state was reduced to a 'ramshackle' protection aimed at compensating (at least to some minimum extent) the costs of reform to the most vulnerable population groups in order to avoid social unrest. The result was severe economic decline accompanied by regressive changes in the structure of GDP and employment, diminishing socioeconomic security of population and rapid exacerbation of inequality. The situation undermined both the initiative and opportunities for human capital accumulation.

The worsening employment structure was accompanied not only by a threefold reduction in average real wages, but also by their redistribution to sections of economy benefiting from globalization - the fuel and energy complex and financial sector (see Table 4). Average wages in the oil and gas sector exceeded average wages in light industry, education and health by 4-6 times to say virtually nothing about agriculture. Taking into account the high incidence of wage arrears in the less fortunate branches of economy the wage gap between privilege and underprivileged sectors began to widen.

The key trend in wage distribution has been increasing dependence on the privileged sectors with a consequent deleterious impact on the diminishing role of education, skill and performance level. It gave a special accent to the problem of 'the working poor'. Unlike the situation in developed economies where this problem is acute mainly for low skilled and less educated workers, in Russia it included a large share of professionals employed in the public sector, including teachers, physicians and librarians. In the 1990s the wages of medical doctors, paramedics, nurses, instructors at preschool centers fell below the poverty line while the wages of teachers and pedagogues exceeded the subsistence minimum by a mere 1.1-1.4 times (See Table 4). 
Table 4 : Relative Wage Levels by Economy Sectors, Russia, 1990-2000

\begin{tabular}{|c|c|c|c|c|c|}
\hline \multirow{2}{*}{ Branch of Economy } & \multicolumn{5}{|c|}{ Wage rate as $\%$ of national average } \\
\hline & 1990 & 1992 & 1995 & 1998 & 2000 \\
\hline Agriculture & 95 & 66 & 50 & 45 & 40 \\
\hline Manufacturing \& mining & 103 & 118 & 112 & 115 & 123 \\
\hline Energy & 121 & 221 & 209 & 203 & 181 \\
\hline Fuel & 148 & 290 & 256 & 237 & 298 \\
\hline Ferrous metals & 117 & 170 & 136 & 136 & 158 \\
\hline Non-ferrous metals & 145 & 250 & 224 & 220 & 278 \\
\hline Engineering & 101 & 87 & 85 & 89 & 95 \\
\hline Light & 82 & 85 & 56 & 51 & 54 \\
\hline Food & 103 & 127 & 118 & 116 & 108 \\
\hline Construction & 124 & 134 & 126 & 127 & 126 \\
\hline Trade \&catering & 85 & 81 & 76 & 82 & 71 \\
\hline Housing \& communal services & 74 & 82 & 102 & 105 & 88 \\
\hline Health \& social security & 67 & 66 & 73 & 69 & 62 \\
\hline Education & 67 & 61 & 65 & 63 & 56 \\
\hline Culture & 62 & 52 & 61 & 62 & 55 \\
\hline $\mathrm{R} \& \mathrm{D}$ & 113 & 64 & 77 & 99 & 122 \\
\hline Finances & 135 & 204 & 163 & 199 & 244 \\
\hline
\end{tabular}

Source: Rosstat, http:/www.gks.ru/wps/wcm/connect/rosstat/rosstatsite/main/, accessed on 3 January 2011.

According to the first round of people's security survey (PSS) conducted by the Institute of Economy in three regions of Russia as a part of ILO Socio-Economic Security Program, among employees with wages below the subsistence minimum, 28.8 per cent possessed university education and another 43.3 per cent non-university tertiary education. The fall in wages in the public sector industries - that have been vital for human development and innovation and concentrating high skilled manpower - was more significant than in other industries. The inevitable result of these developments was the intensification of brain drain from the underprivileged sectors of economy.

Being a strong country with strong military, Russia's industrial economy prior to reforms enjoyed many millions of skilled workers who were engaged in high-tech and innovative activities. With reforms, the economy transformed into a middle income economy heavily dependent on oil and gas with negligible share of innovative goods and services either in GDP or in export. At macro-level the abundant human capital endowment was not used to direct innovation-based growth. On the micro-level the situation is even less encouraging because skilled labour was underpaid in Russia, which meant little or no monetary returns on human capital investment (Gregory and Kohlhase, 1988). During pre-reform times, acquiring tertiary education gave important intangible rewards like status, autonomy at work, higher job satisfaction and better working conditions. Since the turn of the millennium, most of the intangible rewards are gone while individual returns on education remain low. As a result, the relative ranking of national human capital stock can be readjusted downwards to 70-80 per cent of that of the United States if measured by accumulated education, and 10-20 per cent if measured by expected future earnings. This situation raises serious doubts over Russian educational endowments. The main reason for decline of human capital was unemployment, mismatching of jobs, low wages, which resulted in brain-drains from Russia to developed countries where wages and return on education and experience is high. Another cause of the decline of human capital was the unavailability of professionals who were able to manage the 
economy when Russia shifted from planned to market-based economy.

Another negative trend of the 1990s was intensification of classical brain drain from the R\&D sector, which devastated the elite strata of national human resources. According to expert assessments, between 1990 and 2000 public investment in R\&D was slashed by 15-20 times (Фортов, 2002: 43). The fall of public research funds was accompanied by a reduction of corporate spending. During the first decade of reform the majority of Russian firms in the manufacturing sector experienced financial difficulties and, thus, were forced to abandon longterm development goals and accept the strategy of survival. The R\&D expenditures were the first to be cut down by these firms.

Thus, the share of firms contribution in overall R\&D expenditure decreased from 62 per cent to just 6 per cent (Львов and Сорокин, 2005: 133-135). The corporate demand for skilled research personnel almost evaporated, which drove out-migration of scientists and engineers. Employment in R\&D decreased from 2.8 million in 1990 to 1.2 million in 1998 and 0.8 million in 2002. The direct outflow of researchers from the country accounted for a substantial part of the decrease. During the first decade of reforms, Russia lost 60 per cent of mathematicians and about 50 per cent of physicists and biologists. The brain drain reached its peak in the late 1990s when scientists quit Russia in teams, sometimes even managing to relocate abroad in teams (Голдфилд, 2007).

According to data from the national passport-visa service, the emigration of research personnel from Russia reached 5-6 thousand per year. However, independent assessments put the number as at least three times more. Thus, during the decade of economic decline human capital mismatch manifested itself mainly in underemployment (underutilization) of skilled labour. The inevitable result was undervaluation and gradual degradation of a substantial part of accumulated human capital and in some cases irreversible loss of unique technical qualifications and know-how bases, which caused path-dependence traps.

Druska et al. (2002) and Vinogradov (2004) link low returns on human capital in the postSoviet Russia and the inability of highly educated manpower to contribute adequately to economic modernization and sustainable development, to a specific version of human capital mismatch, manifesting itself in a distorted occupational structure of human capital inherited from the centrally planned Soviet economy. In a non-market economy practicing centralized allocation of resources there was little need for professionals in sales, marketing or finance, reflecting the 'technocratic biases of professional education. A large share of students specialized in science and technology education, while training in humanities and social sciences was provided on a relatively modest scale. In the second half of the 20th century, engineers accounted for about one-third of total employment. Sometimes it is argued that market reforms led to per saltumdepreciation and loss of a large portion of the national human capital that was accumulated during the Soviet regime, manifesting in a sharp fall of monetary and non-monetary rewards enjoyed by skilled labour (Нестерова and Сабирьянова, 1998).

\section{Human Capital in India}

India is the second largest populous countries of the world with a total population are around 1.19 billion with annual population growth rate of 1.46 . It had highest illiteracy rate around 74.7 percent in 1950 and average years of schooling was only 0.98. In 2010 the population with zero schooling was 32.7 percent while the year of schooling was around 5.11, which is lowest among selected four emerging economies. Only $20 \%$ population 
According to Ghosh (2010) India has never been a good performer in human development terms, despite the much higher indictors in some states particularly Kerala. Overall, both health and education indicators have lagged well below those in other countries at similar levels of development and with similar per capita income. Banerjee (2008) mention that poverty and hunger have reached alarming level in India particularly in certain states such as Punjab, Kerala, Andhra Pardesh and Assam. The National Family Health Survey for 2005-2006 shows that the proportion of underweight children below the age of five years was 45.5 percent in rural India and 32.7 percent in urban India, indicating hardly any change from the previous survey undertaken 8 years back. One-third of the rural population was also underweight. Anemia, which is an indicator of nutritional deprivation, was also widespred:79.2 percent of children aged 12-23 months and 56.2 percent of ever-married women between 15 and 59 years were found to be anemic. The reason of poor health care services is that health expenditure of central and state governments in India taken together decline from more than 1 percent of GDP in the mid of 1980s to only 0.9 percent in the mid-2000. It means that benefits of economic growth in India have been concentrated and have not "tricked down" sufficiently to ensure improved consumption among the lower income groups. However, the pattern of growth opted in 1980s generated a shift of public expenditure and brought multiplier effects and more employment that benefited the rural poor to some extent (Sen and Ghosh,1994). Thus, in India, rapid economic growth has not contributed to substantial human resources development because of the negative effects of microeconomic policies and processes on food prices and employment generation. The only positive feature in employment patterns was increased opportunities for educated people, largely related to the expansion of IT sector in metropolitan and other urban areas (Ghosh ,2010).

\section{Human Capital in Brazil}

Brazil, the emerging economic giant of Latin America and the world 8th largest economy, has proved to experience a stable and increasing economic growth in the recent past. The economic and industrial growth of Brazil is not sudden rather quite gradual. Its growth performance has been the best one among Latin American countries since 1960s and somewhat parallel to the East Asian export performance. With an annualized 5\% growth rate, it is likely to become world's fifth largest economy overtaking Britain and France in the decade after 2014. Its GDP per capita is 9,567 (PPP US\$) making it one of upper middle income countries with high potential of economic boom given it's rapid industrialization, FDI, boasting export having the biggest share in of meat, coffee, sugar, and fruit But growth is not sufficient, though generally necessary, for achieving economic development. Unequal distribution of income and social spending, high extreme poverty, and the problem of racial discrimination and social inclusion along with larger control of public enterprises, lower education and social spending, and high inflation in the economy have substantially undermined the development prospects of the country. We will address here only three major problems or challenges that obstruct Brazil's development efforts juices, and deep-water oil discovery.

But Brazil, in its attempt to promote development, encounters the problem of low education performance that hinders its ability to reduce poverty and inequality in general. Though it's reported that Brazil's adult literacy rate is $85 \%$, but independent observers have concluded that effective literacy is only $50 \%$ while in similar-income Costa Rica the literacy rate is $95 \%$. According to UNDP data, a third of the poorest fifth cannot attend the primary school and more than $90 \%$ of the poorest fifth cannot afford secondary education. UNDP also concludes that four fifth of the scholarship granted fund chiefly to graduate students goes to the richest 
fifth of the population. This low literacy rate and discriminatory education system has wider repercussions on the development process of Brazil. Lack of education makes people less able to pursue personal enjoyment and social functioning. It reduces their share to the income distribution, less aware about nutrition and health which also make them likely to lead a poor standard of life. Brazil is a rising economy having a huge potential for human development. It's progress in the recent past is also quite satisfactory. In 1993-2005, Brazil experienced five times bigger proportional poverty reduction than both China and India did. Government policy called helped growth trickle down to the poor ensuring a better distribution of grown wealth. Besides in some cases, Brazil outclasses the other BRICs (Russia, India and China). Brazil has the benefit of democracy while China lacks it. There is no internal problem of insurgency, ethnic divisions, religious conflicts and hostile neighbors of the country, unlike India. Smart policy, reduction in poverty and inequality, boasting consumption, new and ambitious Brazilian multinational corporations (i.e. Gerdau, a steelmaker or JBS, soon to be the world biggest meat producing industry) altogether posing a bright indicator that Brazil really takes off in the stage of world economy.

\section{MISMATCH BETWEEN NUMBER AND TYPES OF JOBS}

Despite a very interesting trend in the number of graduates in Brazil, the great majority of these human resources do not seem to be allocated in formal R\& D and engineering activities. Engineers are lacking in certain industries, including IT and there is a mismatch between the number and kind of HRST in industries and supply. Brazil needs a more effective alignment between creation of knowledge and education of human resources in universities with the demand of professional expertise and technological bases for formation of firms and a clear use by companies of the university environment as a source for accumulation of technological capability. The entrants at tertiary level are 7.4 percent. The annual growth in number of entrants in higher education was 10\% per annum between 2000 and 2006 and about $8 \%$ in science and technology. The intensification of growth of human resources in manufacturing shows a tendency that talent is more concentrated in occupations such as plant and machine operators and assemblers. The nature of specific sectors and development stage capability are still in the process of evolving.

\section{Convergence of Human Capital}

Rich countries have much higher stocks of human capital than emerging economies so the question is whether or not past performance in human capital accumulation indicates eventual convergence. The good news is that convergence in human capital has been observed in the past decades. The next question is that if convergence will happen, how many years will it take the emerging economies to catch up with current level of human capital of industrialized countries. It is clarified that the growth rate in human capital may slow when a country achieves a higher level of human capital as illustrated by the slow growth rates in industrialized countries. Hyun H.Son (2010 calculated that average years of schooling in 2010 in China was 8.2 and annual growth rate in years of schooling during 1950-2010 was 2.7. The years need for China to convergence is 10.5. Similarly India average years of schooling in 2010 were 5.1 and annual growth rate in years of schooling during 1950 and 2010 is 3.1 while India needs 24.6 years period for convergence. 


\section{FINDINGS AND RESULTS}

Our study shows that Brazil, Russia, India and China have brought fundamental change in their policy framework to promote human development and accelerate economic growth since 2000. However, human capital development in these countries shows diverging trends. For example, China and India recorded tremendous positive growth which is measured by Human Development Index HDI. According to UNDP Report,2010, China's HDI increased 44.2 percent while India's HDI increased to 33.3 percent during 1990-2010 which shows tremendous improvement in human development indicators particularly improvement in literacy rate and poverty alleviation, healthcare services and level of educational attainment. (See Table 5).

Economic reforms introduced by BRIC brought a dramatic impact on their economies. The human development policies of China, India and Brazil brought a vital change in the social set up and economic environment of these countries, resulting fast economic growth.But economic reformed introduced in Russia could not produce desired results.During pre-reform period, acquiring tertiary education gave important intangible rewards like status, autonomy at work, higher job satisfaction and better working conditions. Since the turn of the millennium, most of the intangible rewards are gone while individual returns on education remain low. As a result, the relative ranking of national human capital stock can be readjusted downwards to 70-80 per cent of that of the United States if measured by accumulated education, and 10-20 per cent if measured by expected future earnings. This situation raises serious doubts over Russian educational endowments. The main reason for decline of human capital was unemployment, mismatching of jobs, low wages, which resulted in brain-drains from Russia to developed countries where wages and return on education and experience is high. Another cause of the decline of human capital was the unavailability of professionals who were able to manage the economy when Russia shifted from planned to market-based economy.

China and accumulated huge wealth by exporting industrial goods while Russia clinched benefit from high oil and gas prices in world market. High commodity prices benefited to Brazil. Based on a Forbes report released in March 2011, the BRIC countries numbered 301 billionaires among their combined populations, exceeding the number of billionaires in Europe, which stood at 300 in 2011. The rising number of billionaires in BRIC shows the prevalence of wide income inequality and regional disparity, creating different classes of people with different income. The increasing income inequality is the serious problem of BRIC and it might become a hurdle in their further economic development and poverty reduction efforts.

\section{Policy Recommendations}

It is suggested that Brazil and Russia pay special attention on the proper utilization of human capital by expanding employment opportunities and by creating jobs that match with skill. China and India should reduce poverty through taxation, i.e.,by taxing the rich and distributing resources among the poor. Now the question is not human capital development, but real question is that policies should be framed for its proper utilization. 
Table 5: Economic and social indicators of BRICs-2010

\begin{tabular}{|c|c|c|c|c|c|}
\hline Countries & China & Russia & Brazil & India & $\begin{array}{l}\text { Total / } \\
\text { Average }\end{array}$ \\
\hline Area $(\mathrm{Km})$ & $9,640,011$ & $17,098,242$ & $8,514,877$ & $3,287,263$ & $28,910,042$ \\
\hline$\%$ of world & 6.5 & 11.5 & 5.7 & 2.3 & 26 \\
\hline GDP US\$ (Mn) & $5,878,257$ & $1,474,828$ & $2,090,314$ & $1,631,970$ & $11,075,369$ \\
\hline$\%$ of world & 9.34 & 2.34 & 3.32 & 2.59 & 17.59 \\
\hline GDP Per Capita (PPP) & 7,544 & 15,612 & 11,273 & 3,408 & 9,459 \\
\hline Population (000) & $1,345,757$ & 140,874 & 193,734 & $1,198,003$ & $2,878372 / 6,979,000$ \\
\hline$\%$ of world & 19.30 & 2.34 & 2.8 & 17 & 41.44 \\
\hline Population growth rate (\%) & 0.48 & -0.51 & 1.26 & 1.46 & 2.69 \\
\hline GDP Growth rate (\%) & 10.30 & 4.00 & 7.49 & 11.1 & 6.56 \\
\hline Primary level enrolment \% & 97.43 & 91.49 & 95.82 & 89.68 & 93.60 \\
\hline Territory level enrolment $\%$ & 7.5 & 64.1 & 16.5 & 10.50 & 24.75 \\
\hline Literacy rate $(\%)$ & 95.9 & 99.5 & 90.0 & 75.0 & 90.10 \\
\hline Spending per student & 12 & 20.5 & 12 & 23 & 16.5 \\
\hline $\begin{array}{l}\text { School life expectancy } \\
\text { (years) }\end{array}$ & 12 & 14 & 14 & 12 & 13.0 \\
\hline Unemployment rate $(\%)$ & 4.1 & 7.6 & 5.8 & 9.4 & 6.7 \\
\hline $\begin{array}{l}\text { Average years of } \\
\text { schooling }\end{array}$ & 8.16 & 9.69 & 7.53 & 5.11 & 7.62 \\
\hline World average years of & & & & & \\
\hline schooling & & & & & 8.12 \\
\hline HDI \% change during & & & & & \\
\hline $1990-2010$ & & & & & \\
\hline (Brazil 2000-2010) & 44.2 & 3.8 & 7.6 & 33.3 & 22.22 \\
\hline
\end{tabular}

Source: International Monetary Funds,World Bank,Barro \& Lee's (2010) data set, UNDP Human Development Report,2010.

\section{Reference}

Abed, George T., and Sanjeev Gupta, eds., (2002), "Governance, Corruption, and Economic Performance" (Washington: International Monetary Fund).

Adams, Richard, (2003), "Economic Growth, Inequality and Poverty: Findings from a New Data Set," World Bank Policy Research Working Paper No. 2922 (Washington:World Bank).

Agion,P. and Hawitt,P. (1992) "A Model of Growth through Creative Destruction". Econometrica. 60 (2): 323-351

Arjona, Roman, Maxime Ladaique, and Mark Pearson, (2001), "Growth, Inequality and Social Protection," OECD Labor Market and Social Policy Occasional Paper No. 51 (Paris: OECD).

Anand, Sudhir, and Martin Ravallion, (1993), "Human Development in Poor Countries: On the Role of Private Incomes and Public Services," Journal of Economic Perspectives, Vol. 7 (Winter), pp. 133-50. 
Baldacci, Emanuele, Maria Teresa Guin-Sui, and Luiz de Mello, (2003), "More on the Effectiveness of Public Spending on Health Care and Education: A Covariance Structure Model," Journal of International Development, Vol. 15, pp. 709-25.

Baldacci, Emanuele, Arye L. Hillman, and Naoko C. Kojo, (2004), “Growth, Governance, and Fiscal Policy Transmission Channels in Low-Income Countries," European Journal of Political Economy, Vol. 20, No. 3, pp. 517-49. Also reprinted in Sanjeev Gupta,

Barro, Robert J., (1996a), “Determinants of Economic Growth: A Cross-Country Empirical Study," NBER Working Paper No. 5968 (Cambridge, Massachusetts: National Bureau of Economic Research).

Jong-Wha Lee, (2010), “International Data on Educational Attainment: Updates and Implications," Center for International Development Working Paper No. 42 (Cambridge, Massachusetts: Harvard University).

Barro, Robert, and Xavier Sala-i-Martin, (1995), "Economic Growth" (McGraw-Hill).

Bassanini, Andrea, and Stefano Scarpetta, (2001), "Does Human Capital Matter for Growth in OECD Countries? Evidence from Pooled Mean-Group Estimates," OECD Economics Department Working Paper No. 282 (Paris: OECD).

Benhabib, Jess, and Mark Spiegel, (1994), "The Role of Human Capital in Economic Development: Evidence from Aggregate Cross-Country Data," Journal of Monetary Economics, Vol. 34, pp. 143-73.

Berry, C.R., and Glaeser, E.L., (2005) "The Divergence of Human Capital Level across Cities." Working paper: Chicago, IL: University of Chicago.

Bidani, Benu, and Ravallion, Martin, (1997), "Decomposing Social Indicators Using Distributional Data," Journal of Econometrics, 77, No. 1, pp. 125-39.

Bils, Mark, and Peter J. Klenow, 2000, “Does Schooling Cause Growth?" American Economic Review, Vol. 90, No. 5, pp. 1160=83.

Bleaney, Michael F., (1996), "Macroeconomic Stability, Investment and Growth in Developing Countries," Journal of Development Economics, Vol. 48, No. 2, pp. 461-77.

Bloom, David, and David Canning, 2003, "The Health and Poverty of Nations: From Theory to Practice," Journal of Human Development, Vol. 4, No. 1, pp. 47-71.

Jaypee Sevilla, 2004, "The Effect of Health on Economic Growth: A Production Function Approach," World Development, Vol. 32, No. 1, pp.1-13.

Blundell, R., and Stephen Bond, 1998, "Initial Conditions and Moment Restrictions in Dynamic Panel Data Models," Journal of Econometrics, Vol. 87, No. 1, pp. 115-43.

Benhabib, J. and M. Spiegel (1994). "The Role of Human Capital in Economic Development: Evidence from Aggregate Cross-Country Data." Journal of Monetary Economics 34, pp. 143-73.

Berman, E., J. Bound and S. Machin (1998). "Implications of Skill-Biased Technological Change: International Evidence." Quarterly Journal of Economics, November, pp. 1245-1280.

Bils, M. and P. Klenow (2000). "Does schooling cause growth?" American Economic Review 90(5), pp. 1160-83.

Bond, Stephen, Anke Hoeffler, and Jonathan Temple, 2001, GMM Estimation of Empirical Growth Models, Nuffield College Economics Paper No. 2001-W21 (Oxford: Oxford University). 
Bruno, Michael, Martin Ravallion, and Lyn Squire, 1998, "Equity and Growth in Developing Countries: Old and New Perspectives on the Policy Issues," in Vito Tanzi and Ke-young Chu, eds., Income Distribution and High Growth (Cambridge, Massachusetts: MIT Press).

Burdekin, Richard C.K., Arthur T. Denzau, and Manfred W. Keil, 2000, “When Does Inflation Hurt Economic Growth? Different Nonlinearities for Different Economies," Working Paper in Economics No. 22 (Claremont, California: Claremont McKenna College).

Carrin, Guy, and Claudio Politi, 1996, "Exploring the Health Impact of Economic Growth, Poverty Reduction and Public Health Expenditure," Macroeconomics, Health, and Development Series, No. 18 (Geneva: World Health Organization).

Castro, Claudio de Moura, and Philip Musgrove, 2001, “Why Education and Health Are More Different than Alike," Economics of Education Series (Washington: World Bank).

Coulombe, Serge, Jean-François Tremblay, and Sylvie Marchand, 2004, "Literacy Scores, Human Capital and Growth Across Fourteen OECD Countries," International Adult Literacy Survey Monograph Series (Ottawa: Statistics Canada).

Deaton, Angus, 2004, "Health in an Age of Globalization," paper prepared for the Brookings Trade Forum (Washington: Brookings Institution).

Deuska, V., Jeong,B.,Keijak,M. and Vinogradov.V (2002) "Assessing the Problem of Human Capital Mismatch in Transitional Economies", William Davidson Institute Working Paper \#467 University of Michigan.

Filmer, Deon, and Lant Pritchett, 1997, “Child Mortality and Public Spending on Health: How Much Does Money Matter?" World Bank Policy Research Working Paper No.1864 (Washington: World Bank).

Filmer, Deon, Jeffrey Hammer, and Lant Pritchett, 1998, "Health Policy in Poor Countries:Weak Links in the Chain," World Bank Policy Research Working Paper No. 1874 (Washington: World Bank).

Fischer, Stanley, 1993, "Role of Macroeconomic Factors in Growth," Journal of Monetary Economics, Vol. 32, pp. 485-512.

Flug, K., A. Spilimbergo, and E. Wachtenheim, 1998, "Investment in Education: Do Economic Volatility and Credit Constraints Matter?" Journal of Development Economics, Vol. 55, pp. 465-81.

Gemmel, N.,(1996), "Evaluating the Impacts of Human Capital Stocks and Accumulation on Economic Growth: Some New Evidence," Oxford Bulletin of Economics and Statistics, Vol. 58, pp. 9-28.

Gupta, Sanjeev, Hamid Davoodi, and Rosa Alonso-Termé, (2002a), “Does Corruption Affect Income Inequality and Poverty?" Economics of Governance, Spring.

Gupta, Sanjeev, Marijn Verhoeven, and Erwin Tiongson,( 2002b), "The Effectiveness of Government Spending on Education and Health Care in Developing and Transition Economies," European Journal of Political Economy, Vol. 18, No. 4, pp. 717-37

Gupta, Sanjeev, Marijn Verhoeven, and Erwin Tiongson, ((2003), "Public Spending on Health Care and the Poor," Health Economics, Vol. 12, pp. 685-96. Also reprinted inSanjeev Gupta, Benedict Clements, and Gabriela Inchauste, eds., Helping 
Countries Develop: The Role of Fiscal Policy (Washington: International Monetary Fund,2004).

Gupta, Sanjeev, Benedict Clements, Emanuele Baldacci, and Carlos Mulas-Granados, 2004, "Fiscal Policy, Expenditure Composition, and Growth," Journal of International Money and Finance, forthcoming. Also reprinted in Sanjeev Gupta, Benedict Clements, and Gabriela Inchauste, eds., Helping Countries Develop: The Role of Fiscal Policy (Washington: International Monetary Fund, 2004).

Gyimah-Brempong, Kwabena, and Mark Wilson,( 2004), "Health Human Capital and Economic Growth in Sub-Saharan African and OECD Countries," The Quarterly Review of Economics and Finance, Vol. 44, No. 2, pp. 296-320.

Hamilton, Lawrence C.(199)1, “How Robust is Robust Regression?" Stata Technical Bulletin, Vol. 2 (July), pp. 21-26.

Hojman, David E.,( 1996), “Economic and other Determinants of Infant and Child Mortality in Small Developing Countries: The Case of Central America and the Caribbean," Applied Economics, Vol. 28, pp. 281-90.

Kim, K., and Moody, P.M., (1992) "More Resources, Better Health? A Cross-National Perspective," Social Science and Medicine, Vol.34, pp. 837-42.

Kaufmann D., A. Kraay, and M. Mastruzzi (2003), "Governance Matters III: Governance Indicators for 1996-2002." World Bank Policy Research Working Paper 3106 (Washington: World Bank).

Krueger, Alan B., and Mikael Lindahl,( 2001), “Education for Growth: Why and For Whom?" Journal of Economic Literature, Vol. 39, No. 4, pp. 1101-1136.

Levine, Ross, and David Renelt, (1992), “A Sensitivity Analysis of Cross-Country Growth Regressions," American Economic Review, Vol. 82, No. 4, pp. 942-63.

Lucas, Robert E. Jr.,( 1988), “On the Mechanic of Economic Development," Journal of Monetary Economics, Vol. 22, pp. 3-42.

Li, Tairan and Richard Florida (2006), "Talent, Technological innovation and Economic Growth in China".

Mankiw, Gregory N., David Romer, and David N. Weil, (1992), "A Contribution to the Empirics of Economic Growth," Quarterly Journal of Economics, Vol. 107, pp. 407-37.

Mauro, Paolo,(1998), "Corruption and the Composition of Government Expenditure," Journal of Public Economics, Vol. 69, No. 2, pp. 263-79.

Mauro, Paolo, (1996), "The Effects of Corruption on Growth, Investment, and Government Expenditure “, IMF Working Paper No. 96/98 (Washington: International Monetary Fund).

McGuire, A., D. Parkin, D. Hughes, and K. Gerard, (1993), “ Econometric Analyses of National Health Expenditures: Can Positive Economics Help Answer Normative Questions?" Health Economics, Vol. 2, pp. 113-26.

Mingat, Alain, and Jee-Peng Tan,(1992), Education in Asia: A Comparative Study of Cost and Financing (Washington: World Bank).

Musgrove, P., (1996), "Public and Private Roles in Health: Theory and Financing Patterns," World Bank Discussion Paper No. 339 (Washington: World Bank).

Noss, Andrew, (1991), "Education and Adjustment: A Review of the Literature," PREM Working Paper WPS 701 (Washington: World Bank). 
Pritchett, Lant, (1996), “Where Has All the Education Gone?” World Bank Policy Research Working Paper No. 1581 (Washington: World Bank).

Pritchett, Lant, and Lawrence H. Summers, 1996, "Wealthier is Healthier," Journal of Human Resources, Vol. 31 (Fall), pp. 841-68.

Psacharopoulos, George, (1994), "Returns to Investment in Education: A Global Update," World Development, Vol. 22, No. 9 (September), pp. 1325-43.

Psacharopoulos, George, and Harry Anthony Patrinos, (2002), "Returns to Investment in Education: A Further Update," World Bank Policy Research Paper No. 2881 (Washington: World Bank).

Rajkumar, Andrew Sunil, and Vinaya Swaroop,(2002), "Public Spending and Outcomes:Does Governance Matter?" World Bank Working Papers No. 2840 (Washington:World Bank).

Romer, Paul,(1986), "Increasing Returns and Long-Run Growth," Journal of Political Economy, Vol. 94, No. 5, pp. 1002-37.- 39 -

Sachs, Jeffrey, and members of the Commission on Macroeconomics and Health,( 2003), Macroeconomics and Health: Investing in Health for Economic Development (Geneva: World Health Organization).

Sen, Amartya , (1999), Development as Freedom (Alfred A. Knopf Inc.: New York).

Schramm,Noemi (2011) "Population-Control policies and their implications for Economic Growth in China", Unpublished Bachelor's Thesis, Department of Economics, University of Zurich,Swizerland.

Schultz, T. Paul, (1993), "Mortality Decline in the Low-Income World: Causes and Consequences," Economic Growth Center Discussion Paper No. 681 (New Haven: Yale University).

Sianesi, Barbara, and John Michael Van Reenen, (2003), “The Returns to Education: Macroeconomics," Journal of Economic Surveys, Vol. 17, pp. 157-200.

Soboleva.Irina (2011) "Pattern of Human Capital Development in Russia: Meeting the Challenge of Market Reforms and Globalization", Institute of Economy Russuan Academy of Science.

Strauss, John, and Duncan Thomas, (1998), "Health, Nutrition, and Economic Development," Journal of Economic Literature, Vol. 36, No. 2. pp. 766-817.

Summers, Lawrence H., (1992), "Investing in All the People: Educating Women in Developing Countries," EDI Seminar Paper No. 45 (Washington: World Bank).Temple, Jonathan R.W., 1999, "The New Growth Evidence," Journal of Economic Literature, Vol. 37, No. 1, pp. 112-56.

Unger.Jens.M, Andreas Rauch, Michael Fres,Nina Rosenbusch (2009), "Human Capital and Entrepreneurial Success:A Meta-analytical review" . Journal of Business Venturing 26 (2011) 341-358.

World Bank, 1993), World Development Report 1993: Investing in Health (New York:

Oxford University Press for the World Bank).

Woszmann, Ludger,( 2003), "Specifying Human Capital," Journal of Economic Surveys, Vol. 17, No. 3, pp. 239-70. 